\title{
CHARISTHEO
}

Jurnal Teologi dan Pendidikan Agama Kristen

Sekolah Tinggi Teologi Anugrah Indonesia

Print ISSN: 2541-5247

http://e-journal.anugrah.ac.id/index.php/JCH

Vol. 1 No. 1, September 2021

Submitted: 2021-06-21

Reviewed: 2021-07-14

Accepted: 2021-08-06

\section{STRATEGI PEMULIHAN PSIKOLOGI JEMAAT PASCA COVID-19 BERDASARKAN KITAB MAZMUR 55}

\author{
Victor Angsono Huatama ${ }^{1}$, Talizaro Tafonao ${ }^{2}$ \\ 1 \& 2 Sekolah Tinggi Teologi Real Batam \\ Email Correspondence: victorhuatama@gmail.com
}

\begin{abstract}
The Covid-19 pandemic outbreak has a traumatic psychological impact on all human beings on this earth, both church members and non-believers. Psychological conditions such as mental stress, anxiety, excessive fear, social asocial (avoiding social interaction) have exist and were experienced by the congregations both during and after Covid-19. This article examines strategies that can be applied (implementable strategies) by churches, pastors, counselors, volunteers and even by congregations themselves to restore the psychological impacts with or without Covid-19 infection. The purpose of this paper is to restore the psychological effects of the congregation by minimizing or eliminating the psychological burdens from heavy to moderate, moderate to small and the small ones can be eliminated. The research method used by the author is a qualitative research method by identifying and formulating the problem and then offering solutions to these problems with the main source based on the exposition and application of the book of Psalms 55: 1-24. The author also uses library sources and literatures, journals and books to complement the research holistically in order to draw comprehensive conclusions. This study found that the recovery of the negative psychological effects of the congregation after Covid-19, both through Christian counseling and self-healing, can be done by exposing and applying the text of Psalm 55: 1-24.
\end{abstract}

Keywords: Strategy, Recovery, Psychology, The Church, Covid-19, Psalm 55

\begin{abstract}
ABSTRAK
Adanya wabah pandemi Covid-19 telah memberikan dampak psikologi traumatik bagi seluruh umat manusia di muka bumi ini baik warga jemaat gereja maupun yang belum percaya. Kondisi psikologi seperti tekanan jiwa (stress), kecemasan, ketakutan yang berlebih, asosial (tidak mau bergaul) nyata ada dan dialami oleh jemaat baik selama maupun pasca Covid-19. Artikel ini mengkaji strategi-strategi yang dapat diterapkan (implementable strategies) oleh gereja, pendeta, konselor, relawan bahkan jemaat sendiri untuk memulihkan psikologi jemaat pasca Covid-19. Tujuan dari penulisan ini, untuk memberikan pemahaman kepada Jemaat dalam menghadapi berbagai problem secara psikologi khusus di masa pandemik. Metode penulisan artikel ini adalah metode penelitian kualitatif dengan mengeksposisi Kitab Mazmur 55:1-24. Penulis juga menggunakan sumber dan literatur perpustakaan, jurnal serta buku yang melengkapi kajian dalam penulisan artikel ini. Hasil kajian ini menemukan bahwa doa, konsistensi dan penyerahan, serta percaya kepada Allah merupakan kunci dalam menghadapi berbagai problem berdasarkan teks Mazmur sebagaimana penjelasan dalam artikel ini. Dengan demikian pemeliharaan Tuhan masih nyata dan relevan sampai saat ini.
\end{abstract}

Kata Kunci: Strategi, Pemulihan, Psikologi, Jemaat, Covid-19, Mazmur 55 


\section{PENDAHULUAN}

Tulisan ini berupaya untuk menjelaskan berbagai problem psikologi negatif yang dihadapi oleh jemaat di masa pandemi baik yang sudah pernah terinfeksi virus Corona maupun yang belum pernah terinfeksi dan diikuti dengan strategi pemulihan berdasarkan eksposisi dan penjelasan teks Mazmur 55:1-24 serta beberapa testimoni psikologi jemaat yang dipulihkan dengan strategi tersebut.

Virus Corona (Covid-19) pertama kali muncul di Wuhan, Provinsi Hubei, Tiongkok pada bulan Desember 2019 dengan daya tular yang masif, cepat dan sangat berbahaya (mematikan) terutama terhadap orang berusia lanjut atau orang yang memiliki penyakit bawaan. Indonesia menjadi Negara ke-22 tersebarnya Covid-19 di Asia sekitar bulan Maret 2020 (Selanno, Kartini, 2021). Pada awal Covid-19 masuk ke Indonesia, menurut Kapusdatinkom BNPB (Badan Nasional Penanganan Bencana (BNPN) Indonesia, Agus Wibowo di bulan April 2020, menyatakan bahwa penanganan Covid-19 dapat menggunakan dua pendekatan atau strategi yakni: 80\% melalui pendekatan Psikologi dan 20\% melalui pendekatan medis. Pendekatan psikologi menjadi ujung tombak, di mana bagi "yang sehat tetap sehat, lalu yang kurang sehat jadi sehat dan yang sakit jadi sembuh," Seluruh umat manusia perlu meningkatkan imunitas, stamina, gizi, istirahat cukup, lalu olahraga serta tidak panik dan selalu gembira, yang mana sangat berguna secara psikologi sebagai ujung tombak penanganan Covid-19 di Indonesia (Wibowo, 2020).

Seiring dengan berjalannya waktu, lebih kurang 1 tahun, penyebaran Covid-19 di Indonesia, masih saja tinggi. Per tanggal 15 Mei 2021, peta penyebaran Covid-19 di seluruh Indonesia termasuk masih cukup tinggi yakni 1.734.285 kasus terkonfirmasi, 93.576 kasus aktif, 1.592.866 kasus sembuh dan 47.823 kasus meninggal (PEN, 2021). Dengan jutaan kasus yang terkonfirmasi dan terus menerus meningkat ke seluruh pelosok Tanah Air, maka baik secara langsung maupun tidak langsung efek psikologi negatif seperti tekanan jiwa (stress), kecemasan, ketakutan yang berlebih, asosial (tidak mau bergaul) diantara warga masyarakat juga terus meningkat walaupun berbagai sosialisasi protokol kesehatan (protkes) dari pemerintah mulai dari 3M (Memakai Masker, Mencuci Tangan 20-30 detik, Menjaga Jarak minimal 1 meter) masih terus digalakkan bahkan menambah 2M lagi yakni Menghindari Kerumunan dan Mengurangi Mobilisasi. 
Jemaat (warga gereja) juga tidak luput dari tekanan psikologi tersebut di atas yang mana tekanannya menjadi semakin meningkat dan merusak kejiwaan seseorang, apabila dihantui lagi oleh kehilangan pekerjaan (PHK), usaha yang semakin lesu dan kebangkrutan di depan mata, serta hubungan suami istri yang terus merosot akibat isu kesehatan dan keuangan keluarga sebagai dampak langsung dari penularan Covid-19. Dalam kajian yang dilakukan oleh Simon dan Anderson menjelaskan bahwa salah satu penyebab terjadinya ketakutan di tengah-tengah masyarakat saat ini yaitu banyak media televisi yang menarasikan Covd-19 ini sangat menakutkan sehingga hal ini mengganggu psikologi setiap orang (Simon \& Anderson, 2020). Menurut Lennox, Covid-19 tidak hanya memberikan dampak terhadap kondisi kesehatan, tetapi juga mempengaruhi kondisi psikologi seseorang, dimana salah satu dampak utamanya adalah perasaan universal bahwa manusia sangatlah rapuh. Banyak dari kita sudah terbiasa dengan dunia yang relatif stabil, di mana kehidupan yang dapat diprediksi dengan akal sehat. Segala sesuatu yang selama ini manusia andalkan lenyap dan manusia ditelanjangi dengan kekuatan-kekuatan yang berada di luar kendali manusia. Orang-orang mengkhawatirkan kondisi kesehatannya, baik fisik maupun psikis; kuatir atas keluarga dan teman-temannya, khususnya kaum usia lanjut dan mereka yang lemah; gelisah atas jejaring sosialnya; persediaan makanan (John C. Lennox, 2020). Menurut Kumowal bahwa penularan Covid-19 telah menyebabkan dan mendatangkan pengaruh dan dampak psikologi negatif terutama kecemasan bagi seluruh umat manusia baik jemaat maupun yang masih belum percaya (Royke Lantupa Kumowal, 2021).

Menghadapi kondisi psikologi jemaat yang sudah terlanjur "dirusak" oleh Covid-19 baik sebagai orang yang sudah terkena Covid-19 (pasien) dan sudah sembuh maupun pasien yang sedang dirawat di rumah sakit serta yang sama sekali belum pernah terkena Covid-19, maka gereja, aktivis ataupun konselor, perlu memiliki suatu strategi yang jitu, tepat serta yang dapat diterapkan (implementable strategies) untuk memulihkan psikologi jemaat pasca Covid-19, supaya psikologi jemaat kembali baik ke sediakala. Menurut Maleachi dalam Widodo menjelaskan bahwa kitab Mazmur mampu menginspirasikan hidup umat beriman dalam mempersepsikan gejala hidup dan membangun suasana batin untuk memaknainya serta mengimani adanya campur tangan Tuhan terhadap gejala hidup tersebut (Widodo, 2021). Dalam hal ini termasuk juga campur tangan Tuhan terhadap efek negatif psikologi karena pandemi Covid-19.

Berdasarkan problem di atas, maka Kitab Mazmur menawarkan suatu solusi kepada umat untuk bergantung penuh kepada Sang Pemberi Hidup, supaya tetap mencari perlindungan di dalam 
Allah melalui FirmanNya. Khusus untuk rasa cemas, kuatir dan ketakutan dalam menghadapi "musuh" Covid-19, Tuhan berfirman dalam Mazmur 55:23, TB, "Serahkanlah kuatirmu kepada Tuhan, maka Ia akan memelihara engkau! Tidak untuk selama-lamanya dibiarkan-Nya orang benar itu goyah." Hal ini juga dialami oleh Daud dimana kesulitan dan pergumulan besar serta stress (tekanan) yang berat dalam menghadapi musuh-musuhnya, Daud tidak perlu takut karena Allah berjanji tidak pernah meninggalkan dia. Allah adalah satu-satunya yang dapat melindungi Daud dan keluarganya dari serangan musuh-musuhnya. Oleh karena itu, Daud berseru kepada Allah yang Maha Tinggi, pemilik langit dan bumi. Daud memohon kepada Allah agar mengirim utusan dari sorga untuk menolong dia. Salah satu peristiwa menyakitkan yang dialami oleh Daud yakni saat Daud dikejar oleh Raja Saul dan hendak dibunuh. Daud merasa nyawanya dalam bahaya, ada ketakutan yang sangat besar, dimana serangan-serangan musuh Daud kapan saja bisa mengancam hidupnya. Dampak yang ditimbulkan adalah susah dan tidak nyenyak tidur, perasaan gelisah dan lelah. Seorang yang gelisah tentu saja tidak bisa tidur tenang karena harus berjaga-jaga terus, hal-hal seperti ini sangat mempengaruhi kesehatan fisik orang tersebut (Mustika \& Objantoro, 2020).

Selama pandemi Covid-19 berlangsung, jemaat juga memerlukan pertolongan psikologi, yang menurut Sabda Budiman dan Susanto, gereja bisa melakukan pelayanan konseling dengan memberikan pandangan yang benar dan positif atas pandemi Covid-19, terus meneruskan memberikan motivasi dan memposisikan diri sebagai gembala jemaat yang baik dengan menjalankan berbagai protokol kesehatan untuk menyembuhkan dan mencegah terjadinya infeksi Covid19 (Budiman \& Susanto, 2021).

Berdasarkan penjelasan di atas, maka rumusan dalam penulisan artikel ini adalah bagaimana para jemaat berupaya dalam menghadapi efek psikologi negatif yang ditimbulkan oleh penularan Covid-19. Oleh karena itu, tujuan penulisan artikel ini untuk memberikan pemahaman kepada Jemaat dalam menghadapi berbagai problem secara psikologi khusus di masa pandemi berdasarkan Kitab Mazmur 55.

\section{METODE}


Tulisan ini menggunakan pendekatan kualitatif, di mana paradigma ilmiah yang bersumber dari pandangan fenomena yakni psikologi jemaat pasca Covid-19, menjadi dasar pijakan pendekatan kualitatif ini. Tulisan ini menggunakan eksposisi (penafsiran) dan aplikasi teks Kitab Mazmur 55:1-24 untuk menjawab pemulihan psikologi jemaat disertai dengan pengamatan lapangan beberapa jemaat yang berhasil pulih dari pengaruh psikologi negatif.

Pendekatan kualitatif lebih mengarah pada penyelidikan kebenaran yang bersifat relative (Sonny Eli Zaluchu, 2020) dan bertujuan untuk mengungkapkan gejala secara keseluruhan serta kontekstual dengan mengumpulkan data berupa referensi perpustakaan, dokumen, jurnal dan Alkitab sebagai sumber utama yang terkait langsung dengan judul penelitian. Adapun proses eksposisi dan aplikasi text Alkitab Kitab Mazmur 55:1-24 digunakan sebagai sumber utama bersama-sama dengan sumber perpustakaan yang aktual lainnya untuk menarik kesimpulan atas hasil penelitian ini. Penelitian ini juga diperkuat dengan data wawancara peneliti di lapangan terhadap beberapa jemaat yang berhasil pulih dari efek psikologis negatif sebagai kesaksian dan konfirmasi bahwa Firman Tuhan masih secara utuh dan sempurna bekerja dalam memulihkan psikologi jemaat pada masa pandemik Covid-19.

\section{HASIL DAN PEMBAHASAN}

Berdasarkan tujuan dari penulisan jurnal ini untuk menyelidiki strategi pemulihan psikologi jemaat pasca Covid-19 berdasarkan Kitab Mazmur 55:1-24, maka pada bagian ini akan membahas secara lengkap efek psikologi negatif yang ditimbulkan karena penularan Covid-19, strategi pemulihan serta eksposisi dan aplikasi teks atas Firman Tuhan Kitab Mazmur 55, yang digunakan untuk mengeliminir dan menghilangkan efek psikologi negatif supaya psikologi jemaat bisa kembali ke status normal pasca Covid-19. Tulisan ini diakhiri dengan data empiris hasil wawancara peneliti sebagai kesaksian dan konfirmasi bahwa Firman Tuhan Mazmur 55 masih bekerja dengan utuh, sempurna dan relevan pada masa pandemic sekarang.

\section{Efek penularan Covid-19 terhadap psikologi jemaat}

Menurut Dosen Program Studi (Prodi) Psikologi Fakultas Kedokteran (FK) Universitas Sebelas Maret (UNS) Surakarta, Rini Setyowati, M.Psi., Psikolog berpendapat bahwa bagi pasien positif Covid-19, dampak psikologis bisa dirasakan antara lain perasaan tertekan, stres, cemas saat di diagnosis positif Covid-19. Penderita bisa merasa cemas atau khawatir secara berlebihan ketika 
privasinya atau identitasnya bocor kepada publik sehingga berdampak dikucilkan oleh lingkungan sekitarnya (HumasUNS, 2021).

Akibat kondisi seperti ini, pasien akan bersikap tidak jujur dengan riwayat penyakit, perjalanan sebelumnya dan pernah kontak dengan penderita Covid-19 lain kepada tenaga medis. Reaksi lainnya bisa berupa penderita merasa cemas atau khawatir tentang hasil yang lambat setelah perawatan medis. Bagi masyarakat luas dapat menimbulkan perasaan tertekan, stres dan cemas dengan pemberitaan mengenai meningkatnya jumlah penderita Covid-19. Rini Setyowati juga berpendapat bahwa pemberitaan yang simpang siur atau kurang tepat dapat memicu stres pada masyarakat yang mempengaruhi hormon stress meningkat sehingga menyebabkan sistem imun yang menurun dan rentan tertular Covid-19.

Keadaan memproteksi diri secara berlebihan seperti mencuci tangan secara terus menerus, membersihkan rumah dan lingkungan secara terus menerus yang dikenal dengan gejala obsessive compulsive disorder (OCD), yakni gangguan mental yang menyebabkan penderitanya merasa harus melakukan suatu tindakan secara berulang-ulang. Bila tidak dilakukan, orang tersebut akan diliputi kecemasan atau ketakutan.

Menurut Dokter Spesialis Kedokteran Jiwa RS Pondok Indah Bintaro, Leonardi Goenawan (Pranita, 2021), yang telah mengidentifikasikan minimal ada tiga tahapan psikologis yang bisa dialami oleh setiap individu selama pandemi Covid-19 yang antara lain:

1. Tahap disrupsi (perubahan berbagai pola hidup)

2. Tahap kebingungan dan ketidakpastian.

3. Tahap penerimaan atau menerima tanpa syarat terhadap kondisi yang ada berkaitan dengan pandemi ini.

Namun tidak semua orang memiliki ketangguhan yang sama untuk mencapai tahap penerimaan. Seseorang yang biasanya mudah tertekan, akan merasakan dampak pandemi ini lebih berat dan terhenti di tahap pertama atau kedua. Menurut data empiris yang dihimpun oleh Ikatan Psikologi Klinis Indonesia (IPK Indonesia) (Ellyvon Pranita, 2021), dari 194 psikolog di 27 wilayah di Indonesia, prevalensi masalah psikologis tertinggi dapat dikategorikan menjadi 6 kelompok yakni:

1. Masalah belajar - Hambatan terkait masalah belajar untuk anak-anak.

2. Keluhan stres - Keluhan stres umumnya adalah masalah psikologis yang secara konsisten banyak ditemukan pada semua kelompok usia. 
3. Keluhan kecemasan - Sama halnya dengan keluhan stres, masalah psikologis yang satu ini juga dialami oleh semua usia.

4. Keluhan mood swing - Keluhan mood swing atau suasana hati yang berubah-ubah di tengah pandemik ini juga dirasakan oleh semua kelompok usia.

5. Gangguan kecemasan - Gangguan kecemasan ini tidak hanya berupa keluhan, melainkan sudah menjadi contributor atas perasaan yang selalu khawatir, cemas atau takut yang cukup kuat sehingga mengganggu aktivitas sehari-hari,

6. Keluhan somatis - Keluhan somatis atau somatik, merupakan keadaan seseorang merasakan rasa sakit di tubuhnya tetapi tidak diketahui penyebabnya secara medis.

Menurut Suaibatul Aslamiyah dan Nurhayati, (Aslamiyah \& Nurhayati, 2021) perubahan psikologis pasien Covid-19 yang paling sering ditemui antara lain: terkejut, turunnya motivasi, sedih, tertekan, insomnia dan membutuhkan motivasi, dimana perubahan psikologis pasien ini melalui tiga tahapan yaitu:

1. Terkejut dan turunnya motivasi pada saat kondisi Pasien dinyatakan ODP (Orang Dalam Pemantauan).

2. Sedih, tertekan, insomnia dan membutuhkan motivasi pada saat dinyatakan Kondisi Pasien Positif Covid-19.

3. Merasa asing dengan kondisi sekitar dan trauma pada saat pasien sembuh dari Covid-19.

Menurut Sulis Winurini dari Pusat Penelitian Badan Keahlian DPR RI, bahwa permasalahan kesehatan mental seperti cemas, depresi, dan trauma karena Covid-19 dirasakan oleh sebagian besar masyarakat Indonesia yang mana terdapat faktor risiko utama seperti jarak dan isolasi sosial, resesi ekonomi, stres dan trauma terutama pada tenaga kesehatan, serta stigma dan diskriminasi pada masyarakat umumnya (Winurini, 2020). Berdasarkan data tersebut di atas, "kecemasan atau kuatir" merupakan gangguan psikologi yang paling sering dialami oleh masyarakat pada umumnya dalam segala usia dan tidak tergantung pada jenis kelamin, ras dan latar belakang kepercayaan. Efek negatif psikologis akibat pandemi Covid-19 sangat nyata dan pasti dialami oleh seluruh lapisan masyarakat. 


\section{Strategi Pemulihan Psikologi Jemaat}

Kamus Bahasa Indonesia Online menjelaskan bahwa strategi bermakna sebagai rencana yang cermat mengenai kegiatan untuk mencapai sasaran khusus (KBBI, 2021). Sedangkan, menurut rujukan kamus yang sama pemulihan, berasal dari kata kerja, pulih yang bermakna kembali (baik, sehat) sebagai semula; sembuh atau baik kembali (tentang luka, sakit, kesehatan); menjadi baik (baru) lagi (KBBI, 2021). Psikologi diperoleh dari bahasa Yunani, yaitu psyche yang berarti jiwa dan logos yang berarti ilmu. Jadi secara harfiah psikologi berarti ilmu jiwa, atau ilmu yang mempelajari tentang gejala-gejala kejiwaan (Simanjuntak, 2016). Jadi strategi pemulihan psikologi jemaat pasca Covid-19 menurut Kitab Mazmur 55:1-24, adalah suatu rencana yang cermat, dari gereja, pendeta, penginjil, konselor Kristen, aktifis atau dari pihak manapun, melalui suatu kegiatan yang sudah terancang dengan rapi baik itu doa bersama, pendalaman Alkitab maupun konseling kristiani, untuk memulihkan kondisi psikologi jemaat yang sempat dirusak/dipengaruhi selama adanya penularan Covid-19, supaya kondisi psikologi jemaat kembali sehat seperti semula, sembuh dan menjadi baik kembali, dengan eksposisi Firman Tuhan dan aplikasi teks Kitab Mazmur terutama pasal 55:1-24. Oleh karena itu, Tafonao menekankan bahwa tugas utama seorang gembala adalah mengajar firman Tuhan supaya anggota jemaat mengalami kedewasaan rohani melalui pengenalan akan Tuhan sehingga segala persoalan hidup saat ini dapat diatasi dengan iman (Tafonao, 2018). Selain itu, sebagai orang yang beriman kepada Tuhan Yesus seharusnya merespon segala sesuatu dengan hati dan pikiran yang tenang tanpa terpengaruh dengan apa yang dilihat dan didengar (Simon, 2020).

\section{Eksposisi dan Aplikasi Teks Firman Tuhan Kitab Mazmur 55:1-24}

Mazmur 55 adalah Mazmur dari kisah dan keadaan Daud saat mengalami kecemasan, gelisah, takut dan gentar serta juga mencatat berbagai keadaan dan respon Daud ketika pemberontakan Absalom (Anak Daud) dan Pengkhianatan Ahitofel, penasihat Daud yang membelot kepada Absalom (Kandou, 2020). Kecemasan, kekuatiran serta kebingungan membuat Daud berada dalam berbagai hal yang sulit, tidak pasti, tidak terprediksi, hidup dalam pelarian kesana kemari, kelihatan jauh dari janji Tuhan. Bahkan dalam ayat 7-8, "Sekiranya aku diberi sayap seperti merpati, aku akan terbang dan mencari tempat yang tenang, bahkan aku akan lari jauh-jauh dan bermalam di padang gunung.", yang mana menandakan kondisi psikologi Daud sudah sampai di titik nadir dan sangat berkeinginan untuk "terbang" dan keluar dari tekanan hidupnya yang 
sungguh sangat luar biasa. Daud, sekalipun telah menjadi raja atas Israel, yang sebelumnya telah mengalami proses yang panjang sebelum menjadi raja, namun kehidupan Daud tetap harus diproses Tuhan, bahkan melalui keadaan dan situasi yang tak pernah terbayangkan dan terprediksi sebelumnya oleh Daud sendiri.

Bentuk perlakuan musuh-musuh Daud (Mazmur 55:4, "karena teriakan musuh, karena aniaya orang fasik; sebab mereka menimpakan kemalangan kepadaku, dan dengan geramnya mereka memusuhi aku."), yang berupa pemberontakan Absalom (Anak Daud sendiri) untuk mengambil alih Kerajaan secara paksa dengan dibantu oleh Ahitofel, penasehat Daud yang sudah berpengalaman dan mengetahui kelemahan serta kekurangan Daud, seolah-olah kekalahan Daud sudah pasti dan pemberontakan Absalom pasti berhasil. Karena berbagai faktor ini, membuat Daud teraniaya dan membawa kemalangan baginya.

Dalam Mazmur 55:5-6, "Hatiku gelisah, kengerian maut telah menimpa aku. Aku dirundung takut dan gentar, perasaan seram meliputi aku." Keadaan psikologi Daud yang sulit, rumit, kompleks, dan ruwet ini datang ke dalam kehidupan Daud tanpa peringatan dulu, tanpa permisi, bahkan tanpa Daud berkesempatan untuk bersiap-siap atau menyadari terlebih dahulu.

Mazmur 55 juga menguraikan respons Daud atas segala kompleksitas kehidupan yang sedang dialami yang antara lain:

1. Berseru kepada Allah melalui doa.

Daud memulai Mazmur ini dengan berseru kepada Tuhan untuk memberikan telingaNya (mendengarkan) doanya dan memohon Allah jangan bersembunyi dari doanya. Ia meminta agar Allah sudi memperhatikan dan menjawab doanya (ayat 1-3a). Daud sedang mengajarkan kepada semua umat manusia bahwa mendekatkan diri kepada sumber kehidupan itu (Allah) merupakan hal yang dalam mengahapi tantangan hidup. Peskett berkata Prayer takes us into the presence of the personal, sovereign, covenant God (Peskett, 1990). Teks ini mengajak setiap orang untuk membangun hubungan secara pribadi dengan Allah melalui doa. Tidak hanya itu Daud mengajar setiap pembaca bahwa diri-Nya mengenal Allah yang berkuasa itu. Mengakui keberadaan-Nya serta meyakini bahwa Allah memahami dan memperhatikan pergumulan umat-Nya, ini adalah salah satu ciri dari pribadi Daud ketika ada dalam masalah berat. Tidak seperti yang dialami oleh manusia saat ini, dimana manusia lebih kecenderung takut dan gelisah pada saat menghadapi masalah. Manusia mulai mencari solusi sesuai akalnya sehat dan paling pantas menurut 
pertimbangan diri sendiri ketimbang berdoa dan berseru kepada Tuhan untuk meminta hikmat, solusi dan belaskasihan Allah atas problem itu.

Berbeda dengan apa yang dilakukan oleh Daud pada saat mengalami kecemasan dan kegelisahan ketika dikejar-kejar oleh musuh-musuhnya, Daud tidak peduli dengan situasi seperti itu namun yang penting baginya adalah mencari hadirat Tuhan (ayat 3b-4). Bila dilihat dari segi strategi Daud saat itu adalah Raja dan Daud bisa saja merencanakan dan melakukan banyak hal dengan sumber daya dan kekuatan yang Daud miliki dalam menggagalkan pemberontakan Absalom, tetapi Raja Daud tidak melakukan hal itu, Daud lebih memilih untuk berdoa dan berseru kepada Allah Israel supaya Allah membantu dia keluar dari permasalahan hidup yang mencemaskan dan mengkhawatirkan ini. Balentine melihat bahwa Daud ini sangat memahami betapa pentingnya membangun relasi kepada Allah melalui doa untuk memohon pertolongan dalam segala situasi yang sangat sulit (Balentine, 1993). Selain itu, Setiawan mengatakan doa adalah suatu ekspresi hubungan perjanjian (covenant relationship) antara manusia dan Allah. Hal ini dapat dilihat dalam Perjanjian Lama di mana Allah telah menetapkan suatu hubungan khusus dengan Abraham dan keturunannya (Setiawan, 2002). Respon pertama Daud dalam menghadapi masalah adalah berseru kepada Allah melalui doa dengan harapan agar segala permasalahan dan gejolak emosi dalam hidupnya dapat dikendalikan dengan hati yang tenang. Apa yang dilakukan oleh Daud ini, hendaknya menjadi pembelajaran iman bagi setiap umat percaya dalam menghadapi segala macam peristiwa yang menakutkan termasuk Covid-19 saat ini yang sedang mewabah. Jemaat Tuhan diajak kembali untuk tetap berharap kepada kepada Allah sebagai pemilik langit dan bumi sebagaimana yang telah dilakukan oleh Daud, supaya pandemik ini bisa segera berakhir atau setidak-tidaknya manusia bisa hidup berdampingan secara damai dengan Corona Virus.

2. Daud melawan Kecemasan, Gelisah, Takut dan Gentar

Mazmur 55:3b-6, “...Aku mengembara dan menangis karena cemas, karena teriakan musuh, karena aniaya orang fasik; sebab mereka menimpakan kemalangan kepadaku, dan dengan geramnya mereka memusuhi aku. Hatiku gelisah, kengerian maut telah menimpa aku. Aku dirundung takut dan gentar, perasaan seram meliputi aku." Daud dalam teks ini memposisikan diri sebagai pengembara yang menangis karena mengalami kecemasan, dimana sikap musuh yang penuh ancaman terhadap dirinya, dilanjutkan dengan perasaan gelisih yang semakin menjadi-jadi, takut dan gentar sampai perasaan seram menguasai keseluruhan hidupnya. Hidup di dunia ini 
seolah-olah akan segera berakhir dan dia akan segera dikalahkan oleh musuh. Hal ini diakibatkan pengkhianatan oleh orang orang terdekatnya (13-15), yaitu Ahitofel, penasihatnya, dan anak kesayangannya, yakni Absalom (2 Sam. 15-17).

Ahitofel memberi pelbagai saran yang tepat dalam keberhasilan Absalom melakukan kudeta (merebut kekuasaan secara paksa) terhadap ayahnya. Dalam kondisi seperti ini, Daud menaikkan permohonan kepada Tuhan dengan sungguh- sungguh (1-3). Rasanya, ia ingin melarikan diri dan pergi jauh dari situasi yang dialaminya dengan mencari tempat perlindungan, bahkan ke padang gurun untuk menghindari masalahnya (7-9). Tetapi ia tidak meninggalkan maupun menyalahkan Tuhan. Daud tetap mempercayai kesetiaan Tuhan. Gerstenberger mengungkapkan bahwa ratapan atau keluhan bukanlah suatu tindakan tidak beriman, tetapi justru merupakan iman yang mendalam.(Gerstenberger, 1991)

Situasi seperti ini juga dialami oleh orang percaya saat ini, dimana penyebaran virus Covid19 semakin masif sehingga semua orang pada takut untuk melakukan segala aktifitas di luar rumah dengan perasaan cemas, gelisah, takut dan gentar, tetapi harus belajar Daud ketika Daud menghadapi persoalan yang menakutkan itu, dia datang kepada Tuhan dengan bersedih dan menangis sepanjang hari, karena dia yakin bahwa Tuhan akan menolong dan menyelamatkannya (17-20). Ia melaporkan segala tindakan kelicikan mereka yang menimbulkan kehancuran (10b-12, 21-22), dan mohon Tuhan mengacaukan serta menghukum mereka (10a,16, 24). Dalam kondisi hati yang berduka, Daud mengajak umat Tuhan untuk menyerahkan segala kekuatiran kepada-Nya dan memercayai Tuhan (23-24).

3. Daud mencari tempat perlindungan dan campur tangan Tuhan

Dalam Mazmur 55:7-9, dimana Daud mulai berkhayal, dengan mengandaikan dirinya bisa terbang seperti merpati, yang bisa terbang kemana-mana untuk mencari tempat yang tenang, aman dan jauh supaya terhindar dari ancaman pihak yang mengintimidasinya dan mendapat tempat perlindungan, namun apa daya secara kenyataan, ia tidak bisa terbang. Di akhir ayat 9, bahkan dia melukiskan dengan metaphor lain bahwa hidup yang penuh ancaman seperti angin ribut dan badai. Persoalan yang dibicarakan dalam konteks perikop ini adalah ketika seseorang dikejar-kejar oleh musuh dan mara bahaya. Dalam ayat 2-9 terlihat sebuah doa memohon pertolongan. Jika diamati ayat ini sepertinya Daud terkesan memaksa Allah untuk bertindak, karena dirinya sedang dalam bahaya. 
Daud merasa tidak ada lagi yang bisa menolongnya kecuali Allah sendiri. Allah adalah sumber perlindungan dan pertolongannya. Menurut Boyles bahwa Mazmur Ratapan itu bukanlah sekedar suatu ratapan yang hanya menangisi kesukaran yang dialami, tetapi tujuan ratapan itu adalah mendapatkan sesuatu dari Yahweh.(Boyles, 1989) Para penafsiran melihat bahwa ratapan Daud mewujudkan suatu permohonannya.(Boyles, 1989) Jelas ratapan ini berbeda dengan ungkapan-ungkapan omelan dan gerutuan orang pada umumnya, tetapi ratapan ini merupakan ungkapan permohonan kepada Allah sebagai bukti bahwa dekat dengan Allah (Webster \& R, 2007).

Dengan kata lain bahwa Daud sama sekali tidak memaksa Allah. Justru, doa tersebut adalah simbol kebergantungan mutlak kepada Allah. Daud percaya bahwa Allah akan bertindak (17). Atas keyakinan tersebut, maka manusia tidak perlu merasa khawatir. Bila diliha secara manusiawi bahwa rasa cemas dan khawatir merupakan hal yang wajar. Tetapi kekhawatiran perlu diserahkan kepada Allah (ay. 23), karena Allah Israel adalah Allah yang mendengar setiap orang yang berseru kepada-Nya.

Penulis melihat bahwa dalam situasi penyebaran Covid-19 saat ini, masing-masing orang mengalami ketakutan yang cukup mencemaskan dan terancam. Ada banyak usaha yang dilakukan oleh manusia dengan harus mengikuti protokol kesehatan yang ketat tetapi ada juga yang terinfeksi. Hal-hal seperti ini yang membuat hati manusia semakin tawar dan seolah-seolah Tuhan tidak menolong dalam situasi seperti ini, tetapi perlu belajar dari Daud bagaimana caranya menghadapi segala ancaman kematian itu. Dalam tulisan Tua menjelaskan pada saat Daud mengalami masalah dalam pergumulan hidupnya, Daud tidak menghadapinya sendiri. Daud berseru pada TUHAN, meminta TUHAN untuk turut campur tangan dalam pergumulannya.(Tua, 2017) Artinya bahwa Daud masih memiliki keyakinan bahwa Tuhan menolongnya. Daud mengerti bahwa Tuhan mengizinkan hal supaya bergantung penuh kepada Allah (ayat 10).

4. Daud percaya dan menyerahkan segal kekuatirannya kepada Allah.

Kondisi yang dihadapi Daud saat itu sangat buruk ay 13-16 melukiskan dimana pemazmur mengalami kondisi yang sangat buruk, dimana orang yang dianggap teman dekat (“...orang yang dekat dengan aku, temanku dan orang kepercayaanku, bergaul dengan baik, masuk ke rumah Allah bersama-sama..”), ternyata menjadi bagian atau bahkan otak dari proses pembusukan dan pembantaian kota. Seandainya pihak lain yang melakukannya, pemazmur masih dapat menerima dan memahaminya. Namun, kini teman dekatnya sendiri yang terlibat, ia pun bingung dan berharap 
agar musuh-musuh disergap oleh maut, biarlah mereka turun ke dunia orang mati sebab hidup mereka penuh kejahatan. Tetapi Daud sangat profesional dalam menghadapi permasalahan tersebut. Akhirnya Daud menyatakan sikap yang berbeda sebelumnya dimana Daud tetap percaya kepada Allah dan Tuhan akan menyelamatkan (Ayat 17-20), dimana lawan akan direndahkan karena mereka tidak takut akan Allah (ayat 20). Dalam mengamati dan memperhatikan semua yang dialami dalam hidupnya, pemazmur memberikan nasihat rohani yang indah dengan menganjurkan agar kita menyerahkan seluruh kekuatiran kita kepada Tuhan dan Ia memelihara serta melindungi kita. Tuhan tidak akan pernah meninggalkan orang benar untuk goyah berlama-lama, dimana pertolongan Tuhan hadir tepat pada waktunya (ayat 23). Akhirnya pemazmur menegaskan lagi sikap hidupnya bahwa "Tetapi aku ini percaya kepada-Mu.". Penegasan pemazmur untuk tetap percaya pada Tuhan diyakini bahwa pada saat tersebut, pemazmur masih dikejar oleh musuhnya untuk dikudeta dan belum menang dari konflik perebutan kekuasaan.

Pada saat pandemik Covid-19 ini yang masih berlanjut dan semua manusia masih mengalami katakutan lalu bagaimana sikap orang menghadapi persoalan ini, apakah sikap kita masih pesimis dengan keadaan? Daud telah memberi pembelajaran berharga bagi semua manusia bahwa penyerahan total kepada Tuhan salah satu kunci utama dalm melepaskan diri dari ketakutan yang dihadapi. Menurut Matthew bahwa Daud percaya dan berserah kepada TUHAN atas apa yang sedang terjadi saat itu.(Matthew, 1997) Artinya bahwa Daud tidak ambil pusing dengan masalah duniawi, karena dia punya TUHAN yang sanggup menolongnya dalam segala macam kesulitan.

Demikian juga bagi anak-anak Allah, jemaat orang percaya yang memiliki Allah yang berjanji kepada umatNya bahwa bila menyerahkan kekuatiran kepada Tuhan maka Tuhan yang akan memelihara anak-anakNya dan membuat tidak akan goyah oleh apapun. Sebagai anak-anak Allah harus sungguh-sungguh menyerahkan kekuatiran kepada Allah. Jangan hanya sebatas perkataan sudah menyerahkan kekuatiran kepada Allah tetapi hanya sebatas di perkataan saja namun masih tetap saja memikirkannya dan berusaha terus dengan kekuatan sendiri untuk mengatasinya, sehingga masih saja memegang masalah tersebut. Anak-anak Tuhan yang menyerahkan kekuatirannya kepada Tuhan akan bersukacita dan mulutnya akan senantiasa mengucap syukur karena percaya Allah yang memeliharanya dan membuat mereka kokoh sekalipun di dalam kesesakan.

\section{Data Empiris dari pengalaman Jemaat}


Berdasarkan hasil wawancara yang dilakukan oleh penulis kepada 3 orang jemaat yang mengalami kecemasan dan kekuatiran selama masa Pandemik Covid-19. Berdasarkan Mazmur 55:1-24 telah bekerja dengan sempurna dalam pergumulan mereka dan jemaat tersebut telah dipulihkan secara utuh. Pada tanggal 13 Mei 2021 dalam sesi Pendalaman Alkitab secara daring, Si A, Jemaat wanita kena Covid-19, isolasi Mandiri di rumah. Semenjak mendapatkan hasil swab positif Covid-19, kecemasan dan kekuatiran telah menyelimuti jemaat ini apalagi mengingat suami tinggal serumah, berumur dan memiliki penyakit bawaan (komorbid), di mana rentan terhadap penularan. Namun selama menjalani pengobatan dan karantina mandiri di rumah, Si A mengikuti terus persekutuan doa, Kebaktian Minggu Gereja secara daring, Pendalaman Alkitab Kamis dan ikut pembacaan Alkitab setiap hari. Dengan dikuatkan oleh Firman Tuhan, salah satunya Mazmur 55 ini, dua minggu kemudian, di-swab lagi, hasilnya Negatif Covid-19, suami di rumahnya sehat tanpa Covid-19.

Pada tanggal 29 Desember 2021, Si B, Majelis Gereja dan Guru Sekolah Minggu, teridentifikasi positif, oleh perusahaannya disuruh isolasi ke Rumah Sakit Khusus Covid Galang. Melalui komunikasi antara penulis dan Si B, didapati bahwa kecemasan masih tetap ada namun dengan keyakinan akan pemeliharaan Tuhan serta kekuatan Firman Tuhan yang secara teratur menemani Si B termasuk Mazmur 55 bahwa infeksi Covid-19 bisa disembuhkan. Perusahaan tetap memberikan gaji selama pengobatan, doa dari jemaat dan keluarga tidak putus-putus. Dua minggu kemudian hasil test Covid-19 negatif untuk jemaat ini.

Pada tanggal 18 Mei 2021 dalam satu sesi kuliah daring dimana penulis adalah salah satu mahasiswa dalam kelas tersebut, Si C, seorang dosen teologi, dalam masa pandemik tahun 2020 berusaha mengganti tempat pengabdian di suatu universitas besar dan ternama, namun selama 3 bulan mengajar, tanpa diberikan gaji dan hanya mau ditempatkan sebagai tenaga pengajar honorer. Kondisi stress, tertekan dan tidak mengerti kenapa ada yayasan yang tidak komitmen dengan apa yang didiskusikan saat interview. Sampai titik nadir kesulitan ekonominya bersama keluarga, jemaat ini dengan setia ditemani Firman Tuhan setiap hari termasuk Mazmur 55, akhirnya berhasil keluar dari tekanan dengan penguatan Firman Tuhan yang dibacanya tiap hari (self healing). Bahkan untuk hari-hari berikutnya, Si C mendoakan pihak yayasan tiap hari.

\section{KESIMPULAN}


Berdasarkan kajian dalam tulisan ini, penulis berkesimpulan bahwa pandemi Covid-19, secara nyata dan pasti telah mempengaruhi psikologi manusia di seluruh dunia termasuk Indonesia baik jemaat maupun yang masih belum percaya. Kondisi psikologi yang sering dialami adalah berupa masalah belajar (susah konsentrasi), tekanan (stress), kecemasan, perasaan yang berubahubah (mood swing), kuatir, cemas, takut, somatis (somatik). Kekuatiran atau kecemasan yang paling sering muncul dengan berbagai alasan baik mengenai masalah medis (kesehatan), masalah ekonomi (Pemberhentian Hubungan Kerja, Pengangguran, Usaha yang lesu/bangkrut).

Dengan adanya efek psikologi negatif bagi jemaat pasca Covid-19, penulis menawarkan strategi pemulihan dengan eksposisi dan aplikasi teks Firman Tuhan yakni Mazmur 55:1-24, dengan metode SKS MKP (Seruan kepada Allah; Konsisten berdoa; Serahkan semua kekuatiran; Mengakui kecemasan, takut dan kuatir; Keyakinan akan pemeliharaan Tuhan; Pahami hati Tuhan) dan data empiris hasil pengamatan 3 orang jemaat yang berhasil dipulihkan efek negatif psikologisnya pada saat pandemi Covid-19.

Tulisan ini dapat memberikan sumbangsih pemikiran baru kepada pendeta, penginjil, konselor Kristen dan aktivis yang memiliki beban pelayanan kepada jemaat yang mengalami efek negatif psikologi akibat Covid-19, supaya memiliki cara dan tindakan yang bertahap serta berkesinambungan dalam membantu jemaat pulih kembali secara total dari efek psikologis negatif akibat Covid-19. Selain itu, tulisan ini dapat juga berkontribusi bagi penulis berikutnya sebagai bahan referensi yang bermanfaat. 


\section{DAFTAR PUSTAKA}

Agus Wibowo. (2020). BNPB Ungkap Strategi Lawan Corona: 80\% Pendekatan Psikologis, $20 \%$ Medis. Web.

Aslamiyah, S., \& Nurhayati. (2021). Dampak Covid-19 terhadap Perubahan Psikologis, Sosial dan Ekonomi Pasien Covid-19 di Kelurahan Dendang, Langkat, Sumatera Utara. Jurnal Riset Dan Pengabdian Masyarakat, 1(1), 56-69.

Balentine, S. E. (1993). Prayer in the Hebrew Bible: The Drama of DivineHuman Dialogue. Fortress Press.

Benedetta Mustika, M., \& Objantoro, E. (2020). Pemanfaatan Mazmur 57 dalam konseling krisis di masa pandemi COVID-19. Davar Jurnal Teologi, Volume 1(Issue 1), 1-8.

Boyles, C. C. (1989). The Conflict of Faith and Experience in the Psalms. JSOT Press.

Budiman, S., \& Susanto, S. (2021). Strategi Pelayanan Pastoral di Masa Pandemi Covid-19 Menuju Pertumbuhan Gereja yang Sehat. PNEUMATIKOS: Jurnal Teologi Kependetaan, 11(2), 95-104.

Ellyvon Pranita. (2021). 6 Masalah Psikologis yang Paling Banyak Muncul Akibat Pandemi Covid-19.

Gerstenberger, E. (1991). Psalms Part 1 with an Introduction to Cultic Poetry. Wm. B. Eerdmans Publishing Company.

HumasUNS. (2021). Dampak Covid-19 Menurut Psikolog UNS. Webpage.

John C. Lennox. (2020). WHERE IS GOD IN A CORONAVIRUS WORLD? (V. Lengkong (ed.); 1st ed.). LITERATUR PERKANTAS JATIM.

Kandou, C. W. (2020). Mazmur 55 - How To Respond When Everything Is Not Responding. Blog.

KBBI. (2021). Kamus Besar Bahasa Indonesia (KBBI) Online. KBBI.

Matthew, H. (1997). Matthew Henry's Concise Commentary On The Whole Bible. Thomas Nelson Inc.

PEN. (2021). Peta Sebaran Covid19.

Peskett, H. (1990). Prayer in the Old Testament Outside the Psalms (D. A. Carson (ed.)). World Evangelical Fellowship,.

Pranita, E. (2021). 3 Tahap Psikologis yang Anda Lalui selama Pandemi Covid-19. Kompas.Com. 
Royke Lantupa Kumowal, H. K. (2021). Pendidikan Agama Kristen Gereja Dalam Menghadapi Kondisi Psikologi Jemaat Akibat Pandemi Covid-19. Jurnal Shanan, Volume 5(Issue 1). Semuel Selanno, Kartini Leidy Prily Rorong, N. A. H. (2021). Gereja Menghadapi Covid-19. Magenang Jurnal Teologi Dan Pendidikan Kristen, Volume 1(Issue 2).

Setiawan, K. A. (2002). Doa Dalam Perjanjian Lama. Jurnal Theologia Aletheia, 1(2), 25-42. Simanjuntak, J. (2016). Psikologi Pendidikan Agama Kristen (5th ed.). Penerbit Andi.

Simon Simon . (2020). Respon Orang Kristen Terhadap Pemberitaan Televisi Mengenai Covid19. Jurnal Gamaliel : Teologi Praktika, 2(2), 114-132.

Simon, S., \& Anderson, L. (2020). Covid-19 Memudarkan Rasa Kemanusiaan Terhadap Sesama Dan Implikasinya Bagi Orang Percaya. Sabda: Jurnal Teologi Kristen, 1(2), 85-104.

Sonny Eli Zaluchu. (2020). Strategi Penelitian Kualitatif Dan Kuantitatif Di Dalam Penelitian Agama. Evangelikal: Jurnal Teologi Injili Dan Pembinaan Warga, 4(1).

Tafonao, T. (2018). Peran Gembala Sidang dalam Mengajar dan Memotivasi untuk Melayani terhadap Pertumbuhan Rohani Pemuda. Evangelikal: Jurnal Teologi Injili Dan Pembinaan Warga Jemaat, 2(1), 36-49.

Tua, E. M. (2017). Respon Daud Dalam Menghadapi Pergumulan: Studi Terhadap Kitab Mazmur 3:1-9. Evangelikal: Jurnal Teologi Injili Dan Pembinaan Warga Jemaat, 1(1), 75. https://doi.org/10.46445/ejti.v1i1.59

Webster, B. L., \& R, B. D. (2007). The Place of Lament in the Christian Life. Bibliotheca Sacra, 4(2), 1-12.

Widodo, P. (2021). Kitab Mazmur: Inspirasinya Bagi Kehidupan Manusia Menyejarah. KHARISMATA: Jurnal Teologi Pantekosta, 3(2), 172-183. https://doi.org/10.47167/kharis.v3i2.59

Winurini, S. (2020). Permasalahan Kesehatan Mental Akibat Pandemi COVID-19. Info Singkat: Kajian Singkat Terhadap Isu Aktual Dan Strategis, 12(15), 13-18. 